\title{
An integraded chemical and micromorphological investigation of humic substances in three podzolized soils of the Netherlands
}

\author{
J. Drozd ${ }^{1}$, A. Jongerius ${ }^{2}$ and St. Kowalinksi \\ ' Department of Soil Science, Agricultural University, Wroclaw, Poland \\ ${ }^{2}$ Soil Survey Institute, Wageningen, Netherlands
}

Accepted: 22 March 1982

Key-words: fractional analysis, humic substances, spectroscopic characterization, humic acids, thin sections, Entic Haplorthod, Typic Haplohumod, Typic Haplaquod

\section{Summary}

The humic substances in three podzolized soils of the Netherlands, viz a 'Holt' podzol (Entic Haplorthod), a 'Haar' podzol (Typic Haplohumod) and a 'Veld' podzol (Typic Haplaquod), were analysed chemically and micromorphologically. Tiurin's method was used for total $\mathrm{C}$ analysis and for fractional analysis of humic substances. The absorption spectra of $\mathrm{Na}$-humates in visible light and infrared spectra were determined for the humic acids. The results of the mentioned analyses were compared with the micromorphology of the organic matter occurring in the three soils.

A distinct difference was found in the translocation and distribution of the principal humus compounds in the 'Holt' podzol on the one hand, and the 'Haar' podzol and the 'Veld' podzol on the other hand. The 'Holt' podzol is characterized by a 'mechanical' illuviation, and the other two profiles by translocation in solution. Good correlations were found between the micromorphological images and the chemical composition of the humic substances. Illuviation cutans occurring in the B horizons of the 'Haar' podzol and the 'Veld' podzol appeared to consist mainly of fulvic acids. The dark humus micro-aggregates characteristic of the 'Haar' podzol and the Ap horizon of the 'Veld' podzol differ in composition of humic substances from the brown micro-aggregates of the 'Holt' podzol. Correlations of the stability of micro-aggregates and their composition were found.

\section{Introduction}

In most mineral soils the content of humic substances is relatively small. Nevertheless, those substances are very important from the pedogenetic point of view. This is particularly evident in podzolized soils where clear profile differentiation 
results from the illuviation of humic substances and their role in the translocation of mineral components.

Consequently, the humic substances in podzolized soils have been the subject of chemical investigations for some decades. Several authors, among others Kononova (1966), Scharpenseel et al. (1964), Scheffer \& Ulrich (1960), Tiurin (1937) and Turski \& Lipińska (1965), have shown that the fractional humus composition in podzolized soils differs considerably from that in other soils. In particular, podzolized soils have higher contents of mobile humus fractions and a lower $\mathrm{C}$-humic acids/C-fulvic acids ratio $\left(\mathrm{C}_{\mathrm{h} . \mathrm{ac}} / \mathrm{C}_{\mathrm{fac}}\right)$. Humic acids in podzolized soils have a relatively simple molecular structure, i.e. a low degree of polymerization (Orlow, 1968; Sapek, 1971; Springer, 1934; Sytek, 1972; Welte, 1956); this has been found by chemical methods as well as by spectroscopic characterization (a rather low absorption in the visible light region and a high optical density ratio $\mathrm{E} 4 / \mathrm{E} 6)$.

Recently more attention has been paid to the study of functional groups occurring in the humic substances of podzolic soils.

Infrared spectrophotometry has shown that humic acids and fulvic acids isolated from the Bh horizon of podzolic soils contain similar functional groups and have almost identical molecular structures. The existing differences are mainly due to different amounts of COOH groups (Schnitzer, 1971).

Nevertheless chemical and physicochemical methods alone do not give us an insight into the relation between the composition of organic matter and its morphology. Probably the only way of answering that question is through a combined chemical, physico-chemical and micromorphological investigation of the organic matter.

This paper deals with such an investigation that was done on three podzolized soils of the Netherlands. Our questions were of two kinds, i.e.:

1) Is there a certain profile differentiation in the composition and morphology of the humus in the soils investigated?

2) Is the fractional humus composition reflected by the micromorphology of organic matter in different podzolized soils?

\section{Materials and methods}

Three soil profiles were investigated, i.e.:

- Profile I: an Entic Haplorthod' or Leptic Podzol' or 'Holt' podzol soil' or Rusty podzolized soil (Gleba rdzawa) ${ }^{4}$.

- Profile II: a Typic Haplohumod' or Humic Podzol' or 'Haar' podzol soil' or Iron-humus soil (Bielica żelasisto-próchniczna) ${ }^{4}$.

- Profile III: a Typic Haplaquod' or Gleyic Podzol' or 'Veld' podzol soil' or Mucky podzolic soil (Gleba bielicowa murszasta) ${ }^{4}$.

\footnotetext{
${ }^{1}$ According to the U.S. Soil Taxonomy (Soil Survey Staff, 1975).

2 According to the FAO soil classification.

${ }^{3}$ According to the Dutch system of soil classification (de Bakker \& Schelling, 1966).

${ }^{4}$ According to the Polish system of soil classification (Kużnicki et al., 1974).
} 


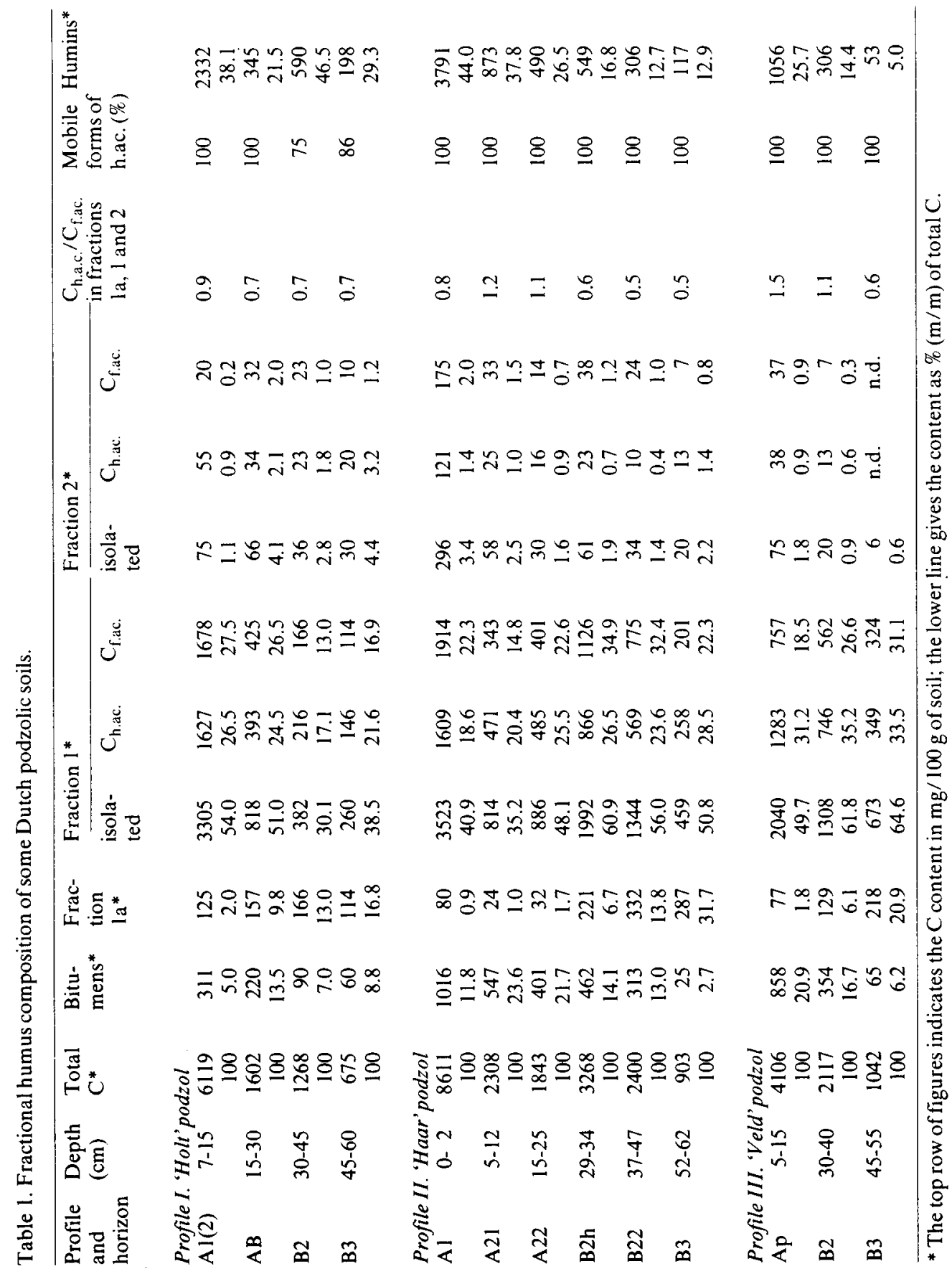

Neth. J. agric. Sci. 30(1982) 
Table 2. Laboratory data of Profile I.

\begin{tabular}{llllll}
\hline Horizon & $\begin{array}{l}\text { Sampling } \\
\text { depth } \\
(\mathrm{cm})\end{array}$ & $\begin{array}{l}\mathrm{pH} \\
(\mathrm{KCl})\end{array}$ & $\begin{array}{l}\text { Clay } \\
(\%)\end{array}$ & $\begin{array}{l}\text { Silt } \\
(\%)\end{array}$ & $\begin{array}{l}\text { Sand } \\
(\%)\end{array}$ \\
A1(2) & $0-6$ & 3.0 & 5.0 & 15.0 & 80.0 \\
B2 & $25-35$ & 4.0 & 5.0 & 16.0 & 79.0 \\
B3 & $50-60$ & 4.3 & 4.5 & 15.0 & 80.5 \\
C & $90-100$ & 4.7 & 1.5 & 10.0 & 88.5 \\
\hline
\end{tabular}

Profile I (de Bakker \& Edelman-Vlam, 1964a; de Bakker, 1979)

This noncalcareous loamy sand soil is situated on an ice-pushed ridge near Doorwerth (about $10 \mathrm{~km}$ west of Arnhem). Permeability is high, and the watertable is very deep. The vegetation is an oak coppice which has not been cut for some decades. The ground-cover consists of bracken (Pteridium aquilinum) and some wavy hair grass (Deschampsia flexuosa).

Under a thin $A 0$ a dark, very friable $A 1(2)$ horizon occurs up to $15 \mathrm{~cm}$ below the surface. This is underlain by a greyish AB. Underneath is a very friable, pellety, dark brown $\mathrm{B} 2$ horizon ( $30-45 \mathrm{~cm}$ below surface), which gradually passes into a brownish yellow B3 horizon. The laboratory data ${ }^{5}$ are given in Table 2.

Profile II (de Bakker \& Edelman-Vlam, 1964b; de Bakker, 1979)

The soil is situated a few $\mathrm{km}$ north of Arnhem (Schaarsbergen) on a Late Pleistocene dune ridge which rises approx. $5 \mathrm{~m}$ above the surrounding ground. The parent material is a noncalcareous sand. Permeability is high and the water-table is found at more than $10 \mathrm{~m}$ depth. The vegetation is heather (Calluna vulgaris) and some seedlings of Scots Pine (Pinus silvestris).

Under a thin sod (A1) a well developed A2 is present. This horizon is underlain by a black horizon ( $24-36 \mathrm{~cm}$ below the surface) rich in illuviated organic matter (B2h); underneath this a brown illuvial horizon with ferri-humic cutans occurs (B22). Laboratory data are given in Table 3.

Profile III (de Bakker \& Edelman-Vlam, 1964c; de Bakker, 1979)

The profile is situated near Maarsbergen, approx. $20 \mathrm{~km}$ east of Utrecht. The soil developed in a noncalcareous medium sand that was deposited by wind during the Late Würm. Permeability is moderate. The water-table fluctuates between about $30 \mathrm{~cm}$ in winter and $100 \mathrm{~cm}$ in summer. Before World War I the area was marshy heathland, but since then it has been used as grassland.

${ }^{5}$ The laboratory data ( $\mathrm{pH}$ and granular composition) of this and the other two profiles are taken from the publications of de Bakker \& Edelman-Vlam and refer to sites that are near the profiles we investigated. This explains differences between the depths of the sampled zones and the depths of the described soil horizons. The organic matter contents (expressed as total C) of the soils investigated are given in Table 1. 
Table 3. Laboratory data of Profile II.

\begin{tabular}{llllll}
\hline Horizon & $\begin{array}{l}\text { Sampling } \\
\text { depth } \\
(\mathrm{cm})\end{array}$ & $\begin{array}{l}\mathrm{pH} \\
(\mathrm{KCl})\end{array}$ & $\begin{array}{l}\text { Clay } \\
(\%)\end{array}$ & $\begin{array}{l}\text { Silt } \\
(\%)\end{array}$ & $\begin{array}{l}\text { Sand } \\
(\%)\end{array}$ \\
A1 & $0-5$ & 3.6 & 2.0 & 4.5 & 93.5 \\
A2 & $10-15$ & 3.8 & 0.5 & 3.5 & 96.0 \\
B2h & $18-20$ & 3.9 & 0.0 & 5.5 & 94.5 \\
B22 & $25-30$ & 4.4 & 1.5 & 2.5 & 96.0 \\
B3 & $50-75$ & 4.6 & 0.0 & 1.0 & 99.0 \\
\hline
\end{tabular}

Underneath a very dark grey Ap horizon a brownish grey B2 horizon occurs (approx. 30-40 below the surface), characterized by coatings of illuviated organic matter on the sand grains. This horizon is underlain by a B3 horizon which shows a gradual thinning of the coatings. The A and B horizons are devoid of iron, as can be proved by the fact that they turn white on ignition. Laboratory data are given in Table 4.

From these soils, samples of the different horizons were taken for:

- total $\mathrm{C}$ analysis and fractional analysis of humic substances according to Tiurin's method (1937);

- physical characterization of humic acids by spectroscopic methods (absorption in the visible light region and infrared spectrophotometry);

- micromorphologic investigations of thin sections.

\section{Tiurin's method}

This method (for a good description see Kononova, 1966) was used because it makes the results of our investigation comparable with those of several other publications on this topic (among others Kononova, 1966; Kozakiewicz, 1966; Tiurin, 1951).

By Tiurin's method the following fractions of humic substances were isolated and determined - as C content - successively (Fig. 1 and Table 1).

1. Humic substances that are soluble in a $1: 1$ mixture of ethanol and benzene. These substances are waxes, fats, resins and related compounds. Although strictly a misnomer, for convenience sake the collective term 'bitumens' has been used by several authors (e.g. Tiurin, 1937; Drozd \& Kowalinski, 1972) to

Table 4. Laboratory data of Profile III.

\begin{tabular}{llllll}
\hline Horizon & $\begin{array}{l}\text { Sampling } \\
\text { depth } \\
(\mathrm{cm})\end{array}$ & $\begin{array}{l}\mathrm{pH} \\
(\mathrm{KCl})\end{array}$ & $\begin{array}{l}\text { Clay } \\
(\%)\end{array}$ & $\begin{array}{l}\text { Silt } \\
(\%)\end{array}$ & $\begin{array}{l}\text { Sand } \\
(\%)\end{array}$ \\
A11 & $0-8$ & 4.6 & 4.0 & 6.5 & 89.5 \\
Ap & $8-20$ & 4.3 & 1.5 & 7.5 & 91.0 \\
B2 & $30-55$ & 3.9 & 0.0 & 0.5 & 99.5 \\
B3 & $60-80$ & 4.2 & 0.0 & 0.5 & 99.5 \\
\hline
\end{tabular}


designate this group of substances. We have followed suit in this paper.

2. Humic substances that are soluble in $0.1 \mathrm{~N} \mathrm{H}_{2} \mathrm{SO}_{4}$ (decalcification). This Fraction la consists of very mobile low-molecular compounds, i.e. free fulvic acids (Kononova, 1966; Kozakiewicz, 1966; Scheffer \& Ulrich, 1960; Springer, 1934; Tiurin, 1937, 1951).

3. Humic substances separated from the decalcified sample by repeated extraction with $0.1 \mathrm{~N} \mathrm{NaOH}$. This Fraction 1 mainly consists of humic acids and fulvic acids which partly are free, partly combined with mobile forms of $\mathrm{R}_{2} \mathrm{O}_{3}$ and with calcium.

4. Humic substances separated during further alternate extraction with $0.1 \mathrm{~N}$ $\mathrm{H}_{2} \mathrm{SO}_{4}$ and $0.1 \mathrm{~N} \mathrm{NaOH}$. The $\mathrm{H}_{2} \mathrm{SO}_{4}$ breaks down the links between the humic substances and the stable forms of $\mathrm{R}_{2} \mathrm{O}_{3}$ and the clay minerals. The bulk of the liberated humic substances is found in the alkaline extract (Fraction 2).

5. Humic substances occurring in the soil residue. These are the very stable nonhydrolysable compounds which belong to the humins.

6. Humic substances that are soluble in $0.1 \mathrm{~N} \mathrm{NaOH}$ without previous decalcification of the sample. They mainly consist of humus compounds that are free and/or combined with mobile forms of $\mathrm{R}_{2} \mathrm{O}_{3}$ (free humus compounds fraction).

By acidification to $\mathrm{pH} \sim 1$ and heating to $80^{\circ} \mathrm{C}$ the extracts of Fractions 1 and 2 and those of the free humus compounds were separated into:

- humic acids (which precipitate as a dark brown gel)

- fulvic acids (which stay in solution).

After isolation of the precipitates by infiltration, and repeated washing with distilled water to remove the $\mathrm{SO}_{4}$ ions, the humic acids were dissolved in hot 0.02 $N \mathrm{NaOH}$. The solution was dried on a water bath, and the C content of the humic acids was determined. Once the $C$ contents of Fractions 1 and 2 of the free humus compounds fraction were known, those of the fulvic acids could be calculated by subtraction.

The amount of humic acids bound with calcium was also found by calculation, being the difference between the amount of humic acids of fraction 1 and that of the free humus compounds fraction.

\section{Spectroscopic methods}

Supplementary qualitative spectroscopic investigations were carried out on the most important group of humic acids, i.e. those separated from Fraction 1.

- Absorption in the visible light region (400-800 $\mu \mathrm{m}$ wavelength), measured in humic acid solutions that were prepared according to the Kononova method (1966), i.e. solution in $0.02 \mathrm{~N} \mathrm{NaHCO}$ to a concentration of $10 \mathrm{mg} \mathrm{C} / 100 \mathrm{ml}$. Results are presented in Fig. 1.

- Measurement of infrared spectra (4000-600 $\mathrm{cm}^{-1}$ wave number; $2.5-15.4 \mu \mathrm{m}$ wavelenght) of humic acids mixed with $\mathrm{KBr}$ in a $1: 200$ ratio. The humic acids were first purified by electro-dialysis to a $\mathrm{pH}$ of 3.4 , and then freeze-dried to preserve their natural properties as much as possible. Results are presented in Fig. 2. For details concerning spectroscopic methods, see among others Schnitzer \& Khan (1972). 

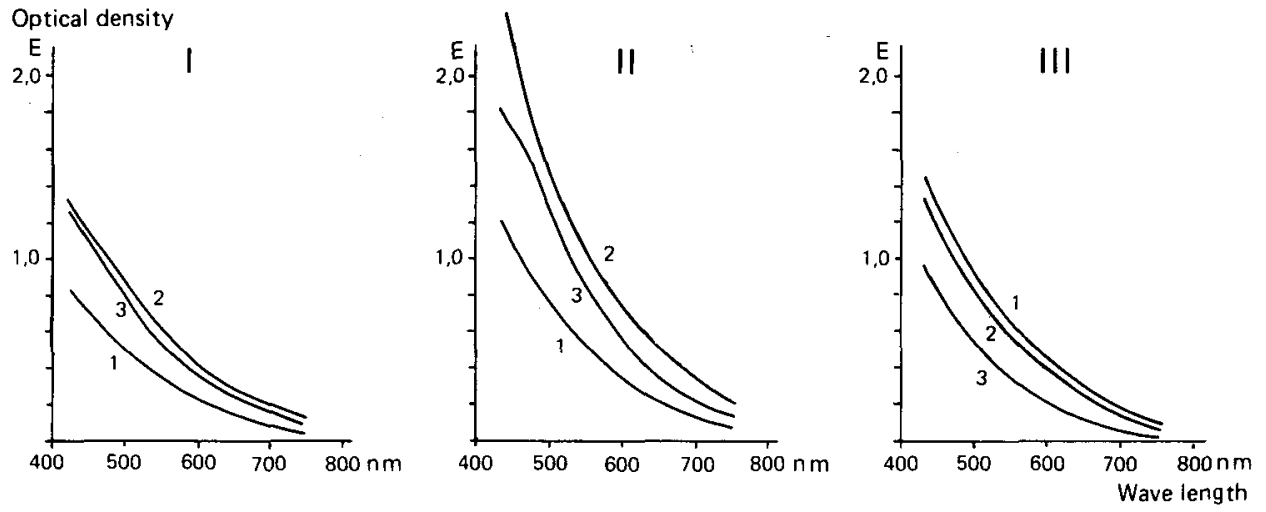

Fig. 1. Absorption spectra in visible light of $\mathrm{Na}$-humates obtained from the three podzolized soils investigated. (Concentration of humic acids: $10 \mathrm{mg} \mathrm{C}$ in $100 \mathrm{ml} 0.02 \mathrm{~N} \mathrm{NaHCO}_{3} ; \mathrm{pH}=7.4$; $\mathrm{E}$ (extinction) $=\log _{10} \mathrm{Io} / \mathrm{I}$.)

I - 'Holt' podzol soil; $1=\mathrm{Al}$ (2) horizon, $2=\mathrm{AB}$ horizon, $3=\mathrm{B} 2$ horizon.

II - 'Haar' podzol soil; $1=\mathrm{A} 1$ horizon, $2=\mathrm{A} 21$ horizon, $3=\mathrm{B} 2 \mathrm{~h}$ horizon.

III - 'Veld' podzol soil; 1 = Ap horizon, 2 = B2 horizon, 3 = B3 horizon.

\section{Thin sections}

Thin sections were made according to the method of Jongerius and Heintzberger (1975). In the description of the sections the term humus micro-aggregates is used in the sense of Jongerius (1957): aggregates some hundreds of micrometers in maximum size, which are composed of aged excrements. Other terms used in the descriptions are: polymorphic (De Coninck et al., 1974; Bullock et al., 1978): organic material without recognizable plant or animal structure which forms a discontinuous mass consisting of small variously coloured patches that usually have diffuse boundaries; monomorphic (De Coninck et al., 1974; Bullock et al., 1978): organic material without recognizable plant of animal structure which forms a continuous mass relatively uniform in colour or density; debris cutan (Jongerius, 1970): a free grain cutan (Brewer, 1964) consisting of an intimate mixture of silt- en clay-sized material, brownish yellow, and usually showing a rough surface; humican (Bal, 1973): a cutan consisting almost entirely of humic substances.

\section{The fractional humus composition}

In this chapter the analytic results as presented in Table 1 will be discussed. The relation with soil micromorphology and the genetic interpretation of the data will be dealt with in the general discussion.

\section{Bitumens}

In the type of soils and horizons analysed, the compound showed a wide variation in fraction of the soil as well as in fraction of total C. In every soil investiga- 
Transmission (\%)
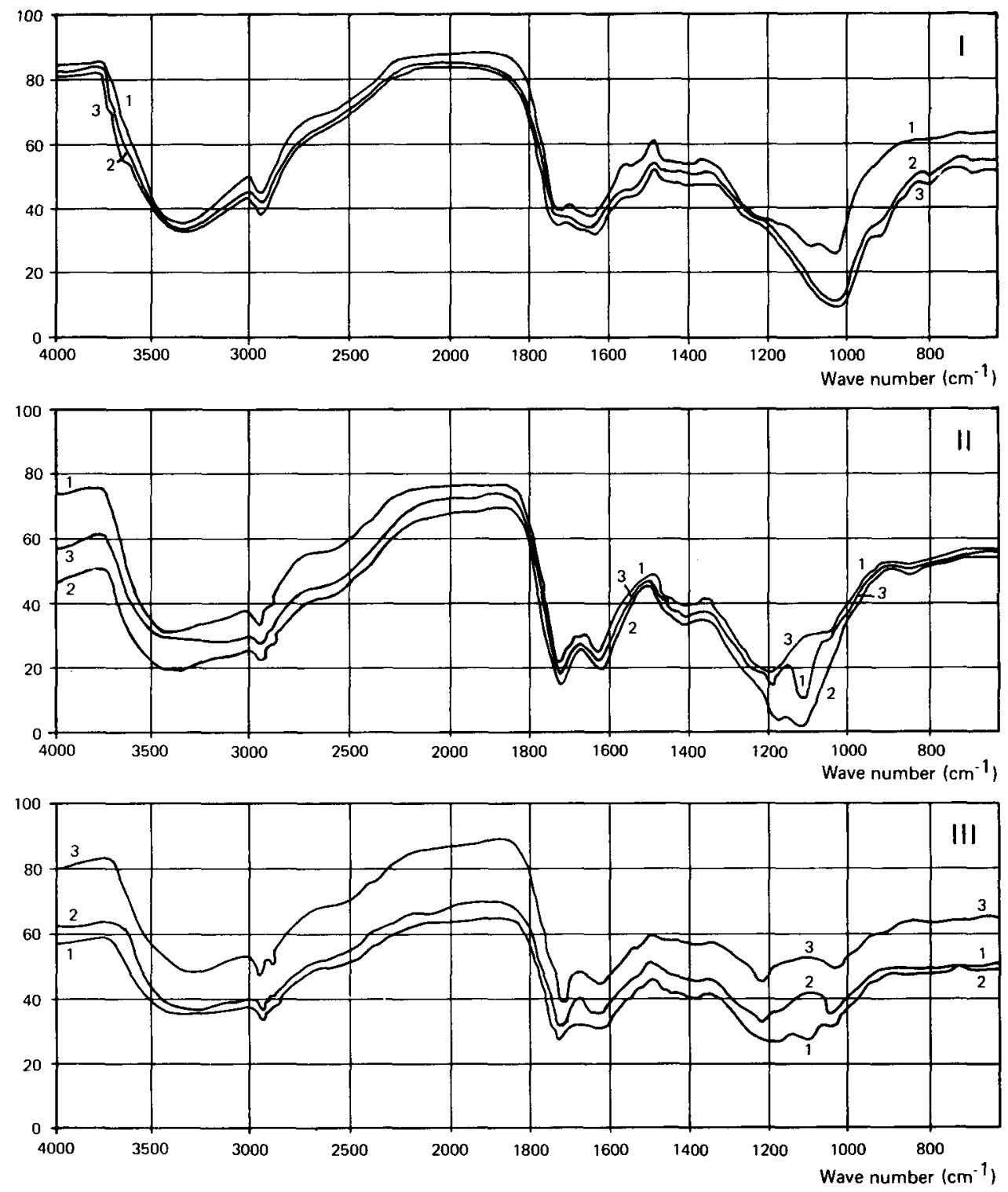

Fig. 2. Infrared spectra of humin acids extracted from:

I - 'Holt' podzol soil; $1=\mathrm{Al}(2)$ horizon, $2=\mathrm{AB}$ horizon, $3=\mathrm{B} 2$ horizon.

II - 'Haar' podzol soil; $1=\mathrm{A} 1$ horizon, $2=\mathrm{A} 21$ horizon, $3=\mathrm{B} 2 \mathrm{~h}$ horizon.

III - 'Veld' podzol soil; 1 = Ap horizon, 2 = B2 horizon, $3=$ B3 horizon. 
ted bitumen fraction of the soil decreased with depth, but in Profile II a small increase should be noted in the B2h horizon. However the situation is different for the bitumen fraction of total C. Profiles I and II showed a maximum in the $\mathrm{AB}$ and $\mathrm{A} 21$ horizons respectively, whereas in Profile III it gradually decreased with depth. In contrast, in the B3 horizon of Profile I there was an increase in this fraction. Finally, bitumen fractions of soil and of total $\mathrm{C}$ occurring in the A1, Ap and A2 horizons of Profiles II and III were markedly higher than those in the corresponding horizons of Profile $\mathrm{I}$.

Fraction Ia (free fulvic acids)

In every profile investigated, the content of Fraction $1 \mathrm{a}$ in total $\mathrm{C}$ increased with depth, but in Profiles I and III this trend was rather weak, whereas the increase was very pronounced in Profile II (from $0.9 \%$ in the Al horizon to $31.7 \%$ in the B3). The same tendency was apparent in the content of Fraction la in soil, except that in Profiles I and II it again decreased markedly below that of the B2 and B22 horizons respectively. The considerable drop occurring in the A2 horizon of Profile II is very striking.

\section{Fraction 1}

From the quantitative point of view this is the most important fraction in the samples investigated.

In Profiles I and III the content of Fraction 1 in soil decreased with depth, but there is a considerable difference between both cases. Profile III showed a very gradual decrease, whereas in Profile I - which was very high in the Al horizon - this content dropped sharply to the AB horizon. In Profile II the course of this content is entirely different: a sharp decrease in the A2 horizon, followed by a pronounced increase in the $\mathrm{B} 2 \mathrm{~h}$, and then a gradual decrease in the $\mathrm{B}$ horizons below. Content of Fraction 1 in total $\mathrm{C}$ showed the same tendency in the latter profile. In Profile I a gradual decrease was visible up to and including the B2 horizon, but in the B3 this content was again somewhat higher. Profile III showed an increase with depth.

\section{Fraction 2}

In all samples the content of this fraction in total $\mathrm{C}$ was very small $(4.4 \%$ maximum). This is mainly due to the fact that these soils are very sandy. The extremely low value $(0.6 \%)$ in the B3 horizon of Profile III is interesting, because it proves that in that horizon no humic substances were combined with stable $\mathrm{R}_{2} \mathrm{O}_{3}$ forms.

The $C_{\text {h.ac. }} / C_{\text {fac. }}$ ratio

In research on the chemistry of humus, this ratio (calculated from Fractions 1a, 1 and 2) is considered to be the best measure of the podzolization process. For an explanation of the ratios presented in Table 1, see the general discussion. 


\section{J. DROZD, A. JONGERIUS AND ST. KOWALINSKI}

\section{The mobile humus compound fraction}

In nearly all soil horizons investigated, the humic acids were entirely of mobile form. In the B2 and B3 horizons of Profile I, however, the contents of mobile humic acids in total $C$ were 75 and $86 \%$ respectively. This means that in these horizons $25 \%$ and $14 \%$ respectively of the humic acids were bound to calcium.

Non-hydrolysable compounds (humins)

In its B2 horizon Profile I showed a relative maximum of humin content in soil as well as in total C. In Profile II the same tendency is visible with regard to the content in soil, i.e. there was a relative maximum in the $\mathrm{B} 2 \mathrm{~h}$ horizon, but the content in total $\mathrm{C}$ gradually decreased with depth. Profile III showed a distinct decrease with depth for both contents.

\section{Spectroscopic characterization of humic acids isolated from fraction 1}

\section{Optical properties of $\mathrm{Na}$-humates}

The absorption spectra of $\mathrm{Na}$-humates in visible light indicate, among other things, the molecular weight and total carbon content of humic acids. High optical densities point to the occurrence of humic acids that have a relatively high content of chromophore groups, i.e. a more complicated molecular structure (Flaig, 1971; Kononova, 1966; Welte, 1956; Scheffer \& Ulrich, 1960).

From Fig. 1 it can be seen that the soils investigated showed clear differences in density of $\mathrm{Na}$-humates. In the $\mathrm{Al}$ (or Ap) horizons the highest density of $\mathrm{Na}$ humates was derived from Profile III. In this profile the density decreased with depth, whereas in Profiles I and II the density was lowest in the A1(2) and Al horizons and at a maximum in the $A B$ and $A 21$ horizons respectively. The differentiation of densities throughout the soil was strongest in Profile II.

\section{Infrared spectra of humic acids}

The infrared spectra presented in Fig. 2 indicate that the humic acids investigated had an essentially similar chemical structure.

All spectra showed a wide and distinctly visible absorption band in the 3250 $3500 \mathrm{~cm}^{-1}$ region. This is attributed to the occurrence of $\mathrm{OH}$ groups which are probably alcoholic and phenolic (Drozd, 1971; Kononova, 1966; Scheffer \& U1rich, 1960; Schnitzer et al., 1959; Schnitzer, 1971; Schnitzer \& Khan, 1972; Sklodowski, 1974). Two other bands occurring in all spectra were situated in the 2930 $\mathrm{cm}^{-1}$ region and in the $2860 \mathrm{~cm}^{-1}$ region respectively. The first band, which was narrow but very distinct, is characteristic for $\mathrm{CH}_{3}$ and $\mathrm{CH}_{2}$ groups, and the (less distinct) second one reflects the vibration of $\mathrm{Ch}$ in aliphatic $\mathrm{CH}_{3}$ groups (Drozd, 1971; Kononova, 1966; Scheffer \& Ulrich, 1960; Schnitzer et al., 1959; Schnitzer, 1971; Sklodowski, 1974).

The most characteristic bands, however, were found in the $1720 \mathrm{~cm}^{-1}$ and the $1630 \mathrm{~cm}^{-1}$ region. The first one proves the occurrence of $\mathrm{C}=\mathrm{O}$ in carboxylic groups and $\mathrm{C}=\mathrm{O}$ stretch of ketonic carbonyl, while the $1630 \mathrm{~cm}^{-1}$ band corresponds with chinonic $\mathrm{C}=\mathrm{O}$ bands (Drozd, 1971; Kononova, 1966; Rosochacka, 
1969; Schnitzer, 1971; Schnitzer \& Khan, 1972; Theng \& Posner, 1967). As both bands were present in all spectra, this means that all the humic acids investigated had aromatic rings and aliphatic chains that contained similar function groups. The intensity of the bands, however, was not the same in all cases, and this enabled us to discern two groups in these humic acids, i.e. those occurring in Profile I and those derived from Profiles II and III. The first group is characterized by a lower intensity in the $1720 \mathrm{~cm}^{-1}$ band compared with that in the 1630 $\mathrm{cm}^{-1}$ band, whereas the second group shows the reverse. Based on Schnitzer's (1971) investigations, this difference can partly be explained by the fact that there were fewer $\mathrm{COOH}$ groups in the humic acids of the 'holt' podzol soil (Profile I) compared with the humic acids occurring in Profiles II and III.

Absorption also occurred in the $1450-1400 \mathrm{~cm}^{-1}$ region. This can be attributed to the occurrence of aliphatic C-H. The absorption at about $1400 \mathrm{~cm}^{-1}$ also proves the presence of carboxylic groups, mostly in the form of salts or anions ( $\mathrm{Ka}$ satochkin et al., 1964; Kononova, 1966; Schnitzer et al., 1959; Schnitzer, 1971). Absorption bands occurring in the $1200 \mathrm{~cm}^{-1}$ region of the spectra belonging to Profiles II and III were characteristic for $\mathrm{C}-\mathrm{O}$ stretch or $\mathrm{OH}$ deformation of $\mathrm{CO}_{2} \mathrm{H}$ (Kononova, 1966; Schnitzer et al., 1959; Schnitzer, 1971). According to other authors (including Farmer \& Morrison, 1960; Turski \& Wincenciak, 1969) the $1200 \mathrm{~cm}^{-1}$ band corresponds with $\mathrm{O}$ directly bound to $\mathrm{C}$ of aromatic rings. The absorption in the $1150-1050 \mathrm{~cm}^{-1}$ region was probably caused by bending vibration of $\mathrm{OH}$, stretching vibration of $\mathrm{C}-\mathrm{O}$ of secondary and tertiary alcohols and C-O-C of cyclic ethers (Drozd, 1971; Farmer \& Morrison, 1960).

According to Sklodowski (1974) humic acids of high molucular weights show a maximum absorption in the $1000-1100 \mathrm{~cm}^{-1}$ region, whereas those of lower molecular weight are characterized by a maximum absorption in the $1100-1200$ $\mathrm{cm}^{-1}$ region. This would imply that the humic acids of the 'Holt' podzol soil (Profile I) had higher molecular weight than those of the 'Haar' podzol soil (Profile II). The spectra of Profile III were not clear in this respect. One should be aware, however, that the $1050 \mathrm{~cm}^{-1}$ bands could partly have been caused by $\mathrm{Si}$ O impurities resulting from preparation (Scharpenseel et al., 1964).

\section{Micromorphology}

\section{Profile I}

Al(2) hor. $\quad 0.15 \mathrm{~cm}$ Upper part: abundant rounded faecal pellets (approx. $40 \mu \mathrm{m}$ ) and many (Fig.3) larger excrements (up to more than $1 \mathrm{~mm}$ ) produced by earthworms and millipedes. Several excrements are intact, but many others are disintegrating due to ageing (Bal, 1973). The excrements consist of brown polymorphic organic matter in which are embedded many cells and very fine usually dark tissue fragments, and much fine silty mineral material only a part of which is loosely bound with the organic matter. Moderate separate fragments of organs and rather large tissue fragments, predominantly rather fresh (much cellulose visible under crossed nicols), but mostly showing continuing humification. Relatively few bare sand grains.

(Fig. 4) Deeper: predominantly rounded faecal pellets of approx. $40 \mu \mathrm{m}$, separate 


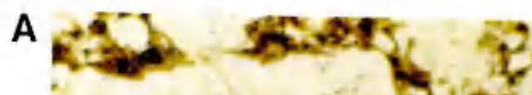
if

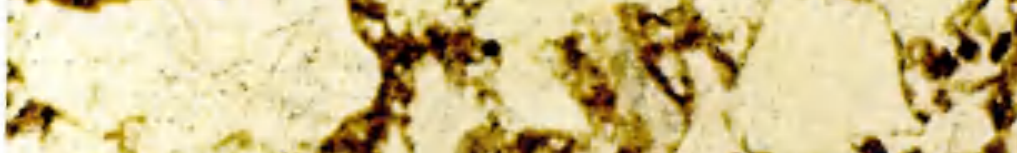

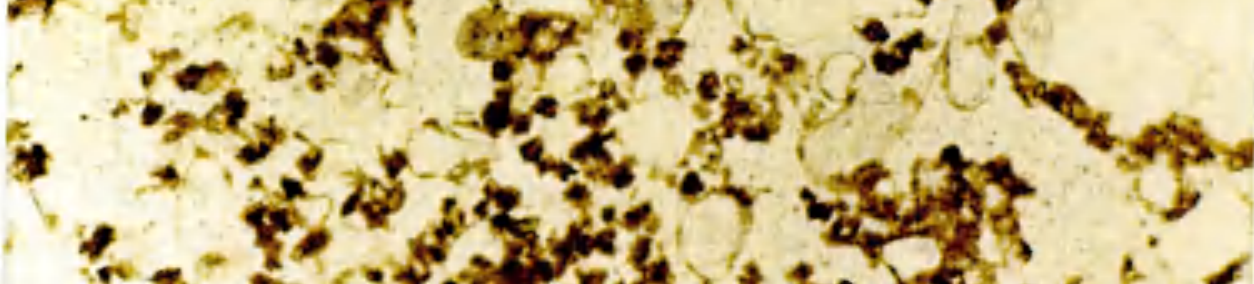

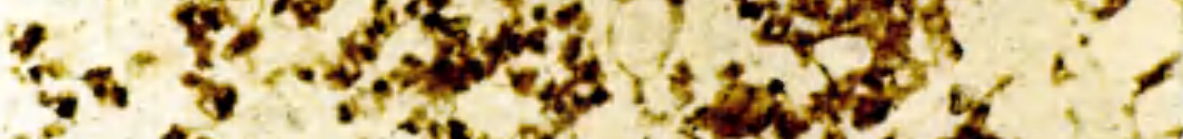

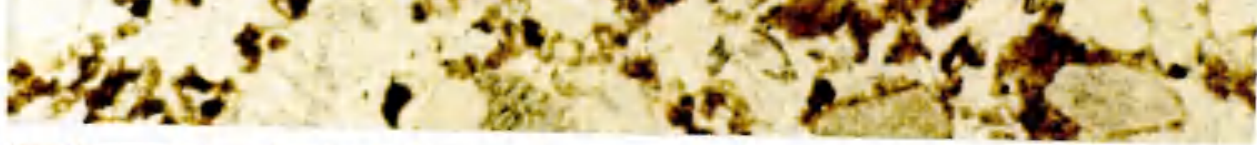

\section{B}

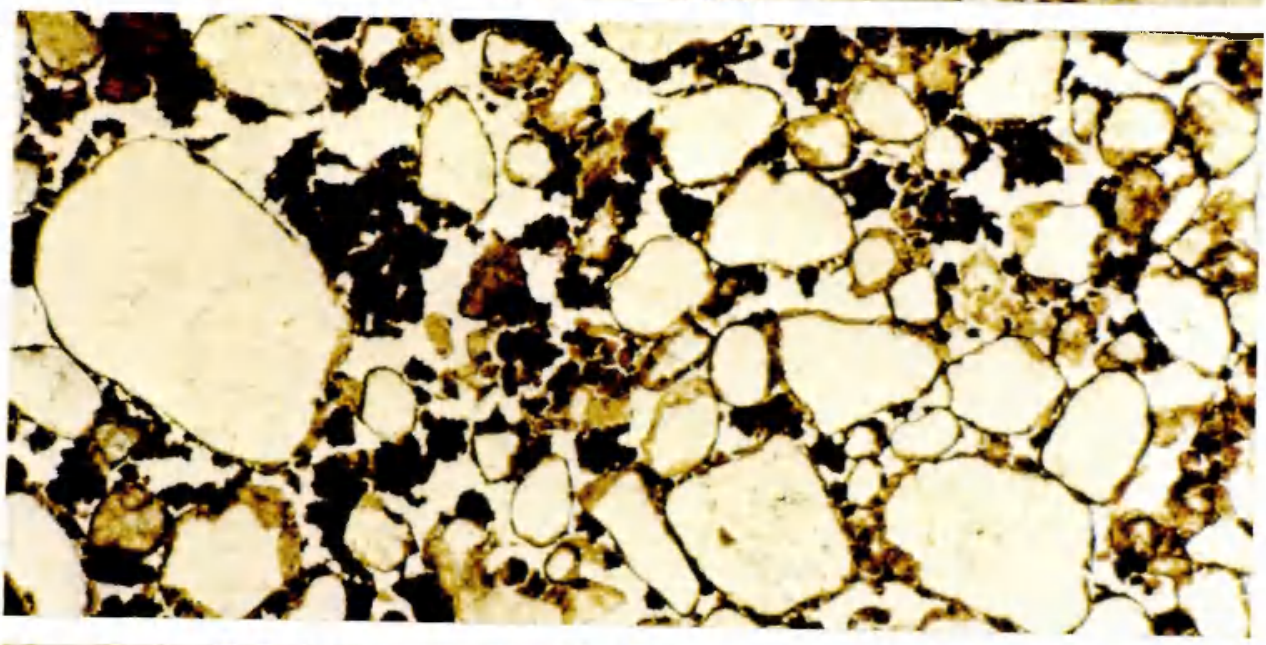

C

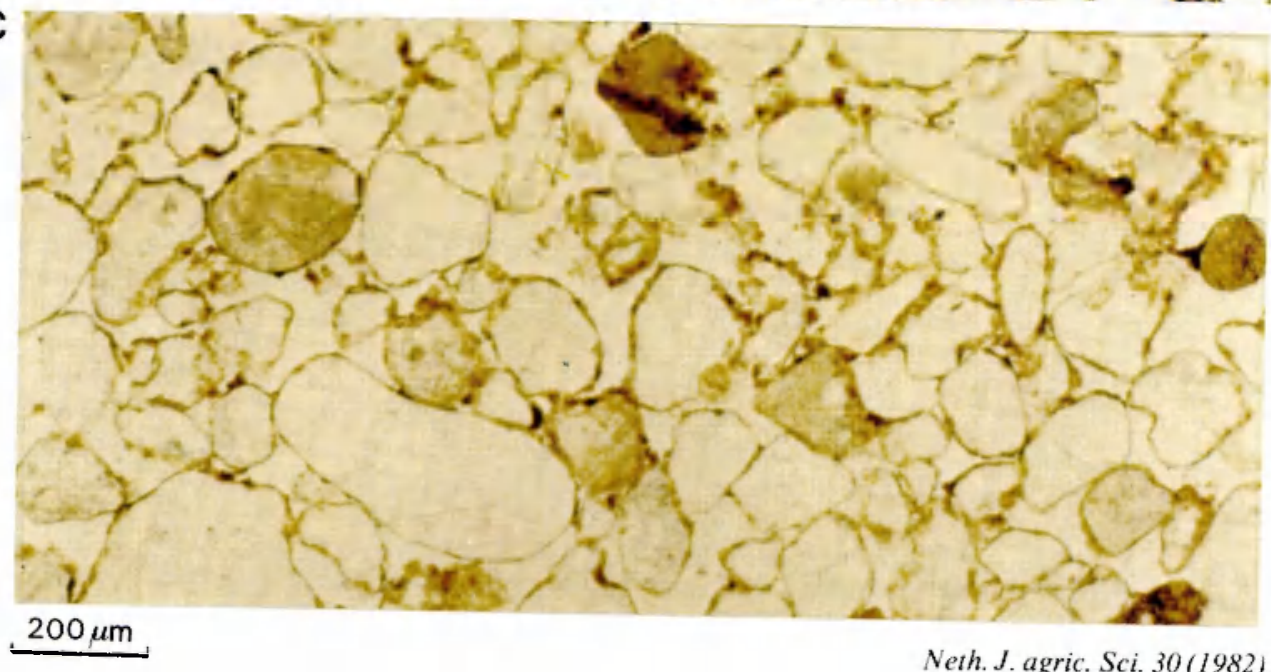

Neth. J. agric. Sci. $30(1982)$ 
$A B$ hor

(Fig. 5)

B2 hor.

(Plate I,A)

B3 hor.

(Fig. 6)

\section{Profile II}

Al hor.

(Fig. 7)

A2l hor.

(Fig. 8) or in loose clusters and ageing larger excrements. In the dark brown polymorphic organic matter many dark to opaque very fine tissue fragments and silty mineral grains. A small content of charcoal. Some brown to dark brown root fragments in different stages of decomposition. Moderate fungal hyphae. More bare sand grains than in the upper part of the horizon.

$15-30 \mathrm{~cm}$ Much less organic matter but still abundant rounded pellets of approx. 40 $\mu \mathrm{m}$, separate and in loose clusters; deeper an increasing number of porous humus micro-aggregates. The polymorphic organic matter is dark brown, downwards grading into brown. Many very fine embedded organic bodies, the content of which decreases with depth, and many loosely bound siltand sand-sized mineral grains. A few fungal hyphae. Few root fragments. In the deeper part of the horizon some traces of thin, brown debris cutans on the free sand grains which are predominantly bare.

$30-45 \mathrm{~cm}$ Moderate faecal pellets of approximately $40 \mu \mathrm{m}$, partly as loose tubulic fillings, partly grouped in small very porous clusters in the groundmass. Many rather compact humus micro-aggregates. The brown polymorphic organic matter contains a moderate amount of very fine dark to opaque organic bodies, some of which have a still recognizable plant structure, and a high amount of mineral grains of silt and fine sand size. Few root fragments. Most free sand grains are partly or entirely covered with brown, rather thick debris cutans of the same composition as the pellets and microaggregates.

Many humus micro-aggregates, resembling those of the $\mathbf{B} 2$ horizon, but still more compact. More and thicker debris cutans. Micro-aggregates and debris cutans are composed of yellowish brown polymorphic organic matter, very fine tissue fragments and many silt and fine sand-sized mineral grains.
$0-2 \mathrm{~cm}$

Abundant porous humus aggregates, varying greatly in size, and composed of a mixture of dark, mostly opaque pellets, approx. $40 \mu \mathrm{m}$, and fine brown tissue fragments with fairly recognizable structures. Few single excrements, approx. 40-150 $\mu \mathrm{m}$ in diameter, composed of dark brown polymorphic and opaque organic material, and very fine brownish fragments. Many larger plant fragments, varying from mostly brownish well preserved ones with recognizable parenchymatic structures, to dark nearly opaque remnants of bark, vessels, etc. Few fungal hyphae. Relatively few sand grains, free partly bare, partly covered with very small humus aggregates, or loosely embedded in the organic material.

$2-12 \mathrm{~cm}$ Many humus micro-aggregates, approx. 50-200 $\mu \mathrm{m}$; mainly weakly porous to compact, consisting of very small opaque particles (partly plant fragments) and brown material with faintly recognizable plant structures; few

Plate 1.

A. Very loose clusters of faecal pellets of approx. $40 \mu \mathrm{m}$, predominantly consisting of brown polymorphic organic matter. Some rather compact humus micro-aggregates of the same colour and composition. Debris cutans around a part of the sand grains. Profile I, B2 horizon, $35 \mathrm{~cm}$ depth.

B. Dark, mainly opaque humus micro-aggregates. Brown monomorphic humicans on the sand grains. Profile II, B2h horizon, $30 \mathrm{~cm}$ depth.

C. Brownish red humicans on the sand grains. Profile III, B3 horizon, $42 \mathrm{~cm}$ depth. 

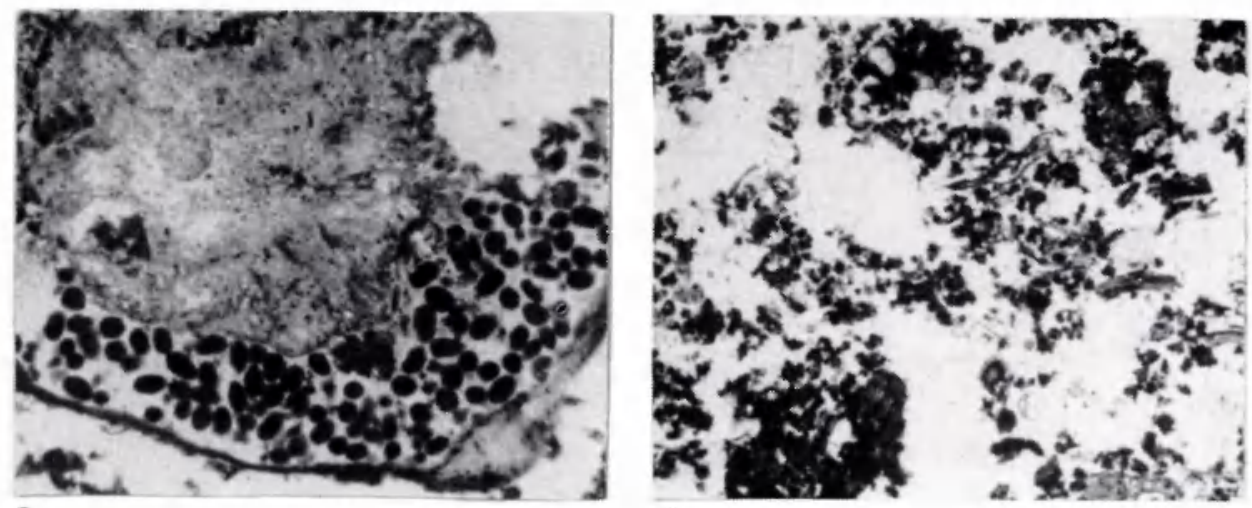

3

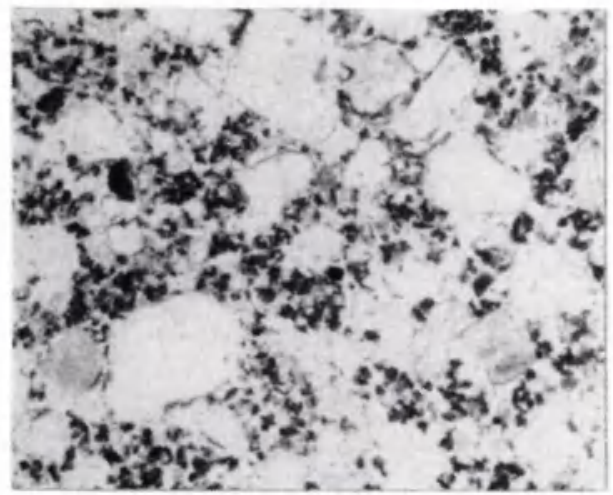

4

5

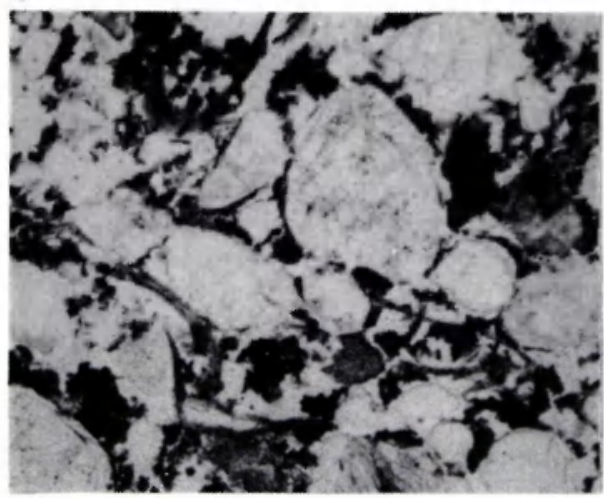

7

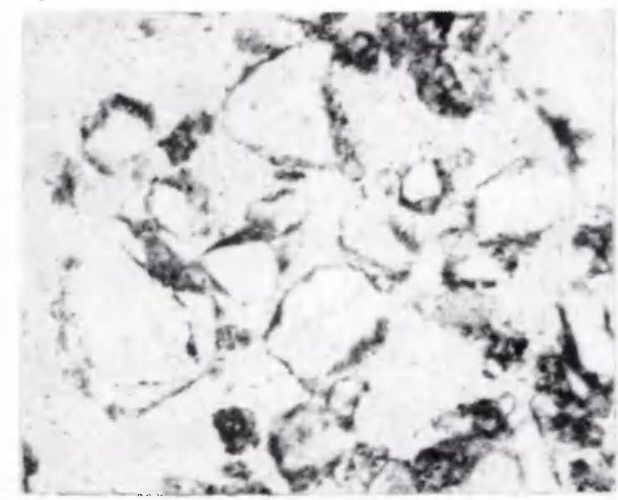

6

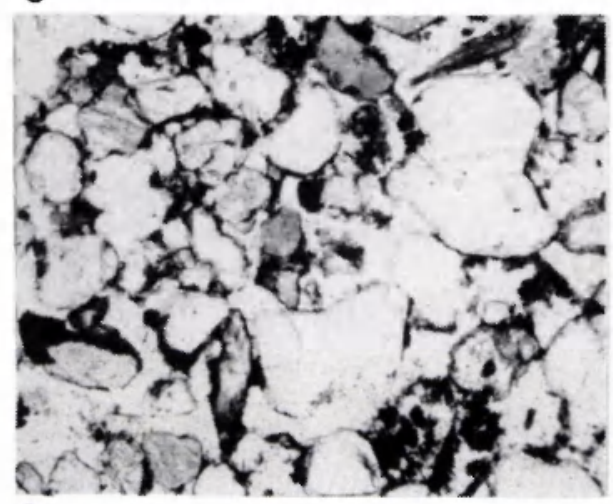

8

Fig. 3. Large fragment of an organ with a zone of intact faecal pellets. Profile I, A 1(2) horizon, $7 \mathrm{~cm}$ depth. $\times 25$.

Fig. 4. Ageing larger excrements (right-hand top corner and left-hand bottom corner) and loose clusters of dominantly dark brown pellets. Profile I. A l(2) horizon, $11 \mathrm{~cm}$ depth. $\times 25$. 

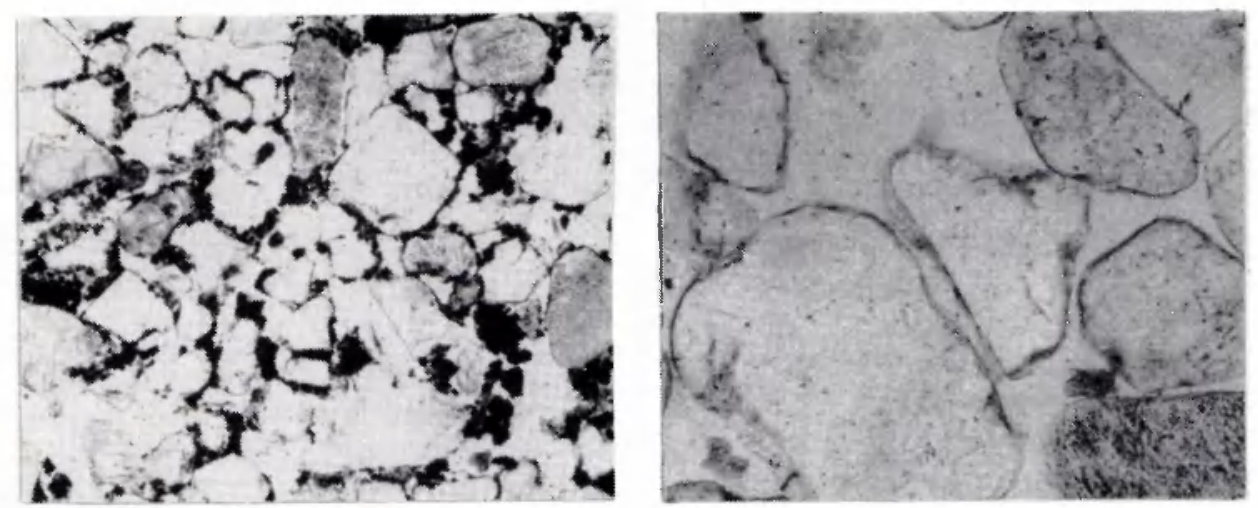

\section{9}

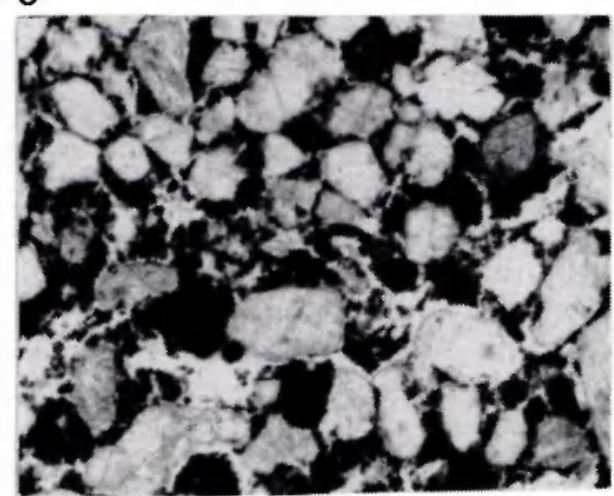

11

10

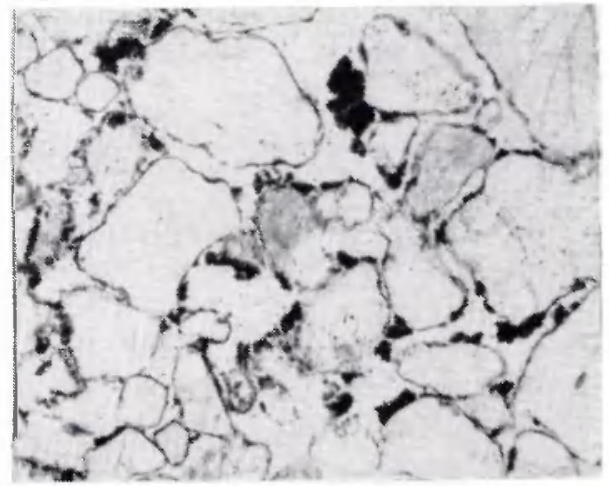

12

Fig. 5. Porous brown humus micro-aggregates filling the simple packing voids. Profile I, AB horizon, $21 \mathrm{~cm}$ depth. $\times 25$.

Fig. 6. Debris cutans around sand grains, and (right-hand top and bottom corner) yellowish brown. rather compact humus micro-aggregates. Profile l, B3 horizon, $55 \mathrm{~cm}$ depth. $\times 40$.

Fig. 7. Porous humus aggregates of strongly varying size. Many of the smallest aggregates are on the bare sand grains. Brownish intact roots are visible, particularly in the centre. Profile II, A l horizon, I cm depth. $\times 40$.

Fig. 8. Many, usually very small. weakly porous to compact, brownish black humus micro-aggregates, partly on the otherwise bare sand grains. Profile II, A21 horizon, $12 \mathrm{~cm}$ depth. $\times 40$.

Fig. 9. Moderate humus micro-aggregates, more opaque than in the A21 horizon. Many sand grains are partly or entirely covered with very small opaque organic matter particles. Profile II, A22 horizon, $22 \mathrm{~cm}$ depth. $\times 40$.

Fig. 10. Thin, light brown monomorphic humicans around sand grains. Profile II, B3 horizon, $60 \mathrm{~cm}$ depth. $\times 100$.

Fig. 11. Many humus micro-aggregates of varying size. The organic matter is dark blackish brown, grading into opaque. Most sand grains are bare, but locally there are organic cutans. Profile III, Ap horizon, $6 \mathrm{~cm}$ depth. $\times 40$.

Fig. 12. Rather few and small humus micro-aggregates, reddish brown and black. On the sand grains brownish red monomorphic humicans, locally covered by small micro-aggregates. Profile III, B2 horizon, $33 \mathrm{~cm}$ depth. $\times 40$. 


\section{J. DROZD, A. JONGERIUS AND ST. KOWALINSKI}

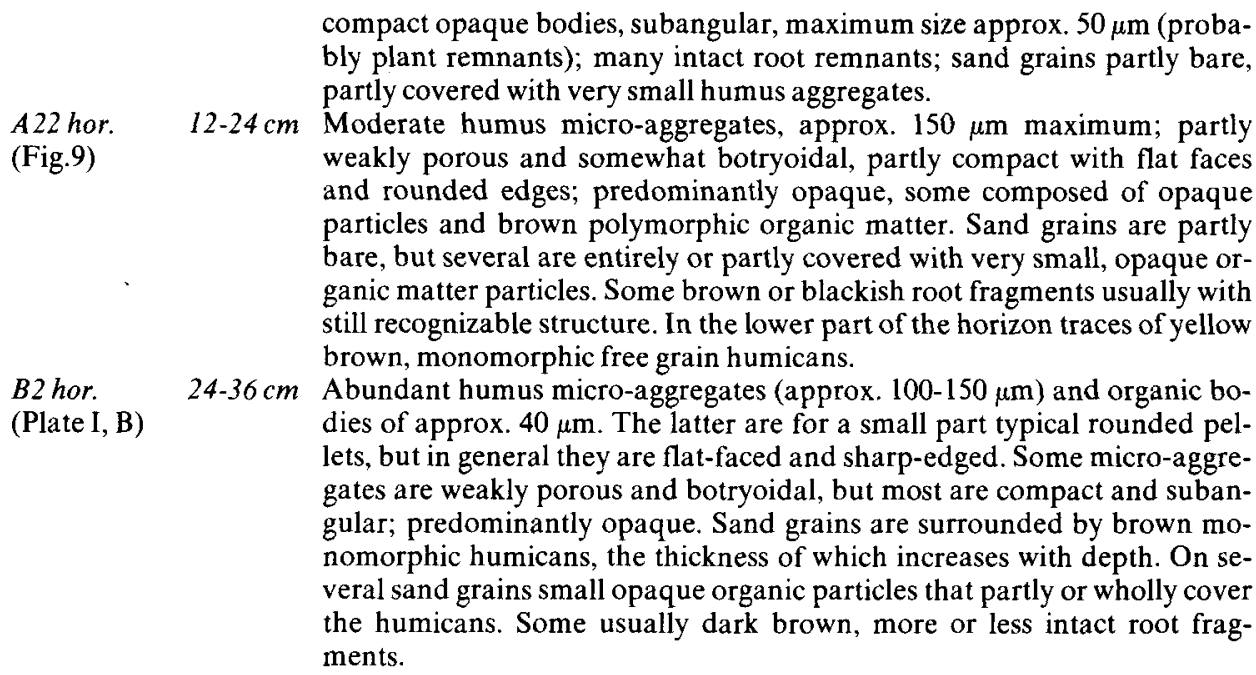

$B 22$ hor. $\quad 36-52 \mathrm{~cm}$ Relatively few humus micro-aggregates, predominantly not larger than 60 $\mu \mathrm{m}$, varying in shape from rounded to very irregular sharp-edged, for a small part larger (approx. 100-150 $\mu \mathrm{m}$ ), rather compact to compact, weakly botryoidal to subangular; partly opaque, but predominantly dark brown and polymorphic. Strongly developed brown monomorphic humicans on sand grains, locally covered by some small opaque organic aggregates. Some strongly humified dark brown to blackish opaque root fragments.

B3 hor. $>52 \mathrm{~cm}$ Sand grains covered by thin, light brown monomorphic humicans; fibres (Fig. 10) the same, but cutans are much thicker.

\section{Profile III}

Ap hor. $\quad 0.30 \mathrm{~cm}$ Abundant humus micro-aggregates, strongly varying in size, mainly up to (Fig. 11) $400 \mu \mathrm{m}$ maximum, but also some that are up to $1 \mathrm{~cm}$; ranging from porous botryoidal to compact subangular. Organic matter essentially polymorphic, but mainly very dark blackish brown, frequently grading to opaque. Mainly bare sand grains, but locally cutans of the same composition as the micro-aggregates. Some strongly humified woody plant fragments.

B2 hor. $\quad 30-40 \mathrm{~cm}$ Few humus micro-aggregates, mainly 50-150 $\mu$ m rather compact, subangu(Fig. 12) lar and angular, mainly polymorphic, reddish brown and black. Former root channels containing larger root fragments with still partly recognizable structure, reddish brown to brownish black, and small dark reddish brown polymorphic faecal pellets (approx. 25-35 $\mu \mathrm{m}$ ). Some isotubules containing brownish polymorphic humus in which many sand grains are embedded. Free grain humicans brownish red, monomorphic, locally covered by small micro-aggregates.

B3 hor. $\quad>40 \mathrm{~cm}$ Same kind of humicans as in the A2 horizon, gradually becoming thinner (Plate I, C) with depth. Sporadic small humus micro-aggregates of the same colour and morphology as in the A2. 
HUMIC SUBSTANCES IN THREE PODZOLIZED SOILS

\section{General discussion}

\section{Profile I}

As can be seen from Table 1, the quantity and relative content of humins, i.e. non-hydrolysable compounds that partly or entirely consist of very fine remnants of plant tissue, were largest in the B2 horizon. This peak is in good agreement with the concept of mechanical illuviation (Jongerius, 1957; Jongerius \& Schelling, 1960) or mecaconcentration (Jongerius, 1970). According to this concept, in 'Holt' podzol soils aged faecal pellets (which still contain very fine plant ' fragments) or their fragments are transported from the A0 and A1(2) horizons by percolating water to a certain depth (the B horizons), where they form humus micro-aggregates.

The content of Fraction 1 in soil and its component substances (humic acids and fulvic acids) decreased with depth in this profile, as did the contents of that fraction in total $\mathrm{C}$, at least up to and including the $\mathrm{B} 2$ horizon. This means that humic substances belonging to Fraction 1 did not translocate, even though they were free and/or mobile compounds. This agrees with the results obtained from the infrared investigation, which revealed that in this profile the molecular weight of the humic acids belonging to Fraction 1 was fairly high.

Because contents of Fraction 2 both in soil and in total C were low in Profile I (as in the other profiles), Fraction 2 is not important for genetic interpretation.

The $\mathrm{C}_{\mathrm{h} . \mathrm{ac}} / \mathrm{C}_{\mathrm{f} \text {.ac. }}$ ratios are more interesting in this respect. The relatively small decrease of $\mathrm{C}_{\text {h.ac. }} / \mathrm{C}_{\text {f.ac. }}$ ratios from 0.9 in the $\mathrm{Al}(2)$ horizon to 0.7 in the lower horizons indicates that there is only a weak tendency for fulvic acids to accumulate in the B horizons. As shown in the analytic data, this particularly concerns the very mobile fulvic acids of Fraction la. It is remarkable that there were no micromorphological indications of translocation of fulvic acids, for these were visible in Profiles II and III as light brown humicans around sand grains (see below). This means that, if fulvic acids have translocated, they have been absorbed by the humus micro-aggregates. However, it is also possible that the downward increase of Fraction la is due to continuing formation of fulvic acids during the process of mechanical illuviation of pellety material.

The brown micro-aggregates particularly common in the B2 horizon of Profile I are not stable. They disintegrate easily, a process that results in the formation of debris cutans around the sand grains. In our opinion, this rather low stability is due to the occurrence of fulvic acids in the micro-aggregates.

\section{Profile II}

The Al horizon of this profile had the highest quantity of total $\mathrm{C}$ of all the horizons investigated. This quantity decreased markedly in the A21 horizon and (in particular) in the A22 horizon, was rather high again in the B2h horizon, and then gradually decreased in the $\mathrm{B}$ horizons below. The quantities (and relative contents) of Fraction 1 and of the humins followed the same trend. In contrast, bitumens reached a maximum content in the $\mathrm{A} 21$ horizon.

The content of Fraction la in soil (which represents very mobile low-molecu- 
lar humus compounds) was low in the A2 horizons, and then increased sharply to a maximum in the B22 horizon. The content of Fraction la in total C increased strongly from the $\mathrm{A} 1$ horizon to the $\mathrm{B} 3$ horizon.

To a certain extent, both contents followed the same trend, i.e. a minimum in the $\mathrm{A} 21$ horizon and a maximum in the $\mathrm{B} 2 \mathrm{~h}$ horizon.

The $\mathrm{C}_{\mathrm{h} . \mathrm{ac}} / \mathrm{C}_{\text {f.ac. }}$ ratios showed the reverse tendency, i.e. they were at a maximum in the A2l horizon and decreased with depth in the B horizons.

These results clearly point to a translocation of some fractions of humus compounds, and especially to a strong illuviation of fulvic acids into the B horizons. The removal of fulvic acids from the $A$ horizons brought about the relatively high content of bitumens in the A2 horizons. This fact probably led to the rather high physical stability of the micro-aggregates occurring in these horizons.

Summarizing, it can be said that in this profile the distribution of the fractional humus compounds throughout the profile (in particular that of Fractions la and 1 , and of the bitumens) very clearly reflects the typical podzolization process.

The micromorphological observations confirm the above-mentioned conclusions. The brown, monomorphic humicans that envelop the sand grains in the $B$ horizons are, in our view, mainly composed of fulvic acids: it should be stressed that the humicans also contain some iron and probably some bitumen, but their colour is predominantly determined by the fulvic acids. The dark humus microaggregates that occurred in the intergranular spaces in the B2h horizon and (to a lesser extent) in the B22 horizon are, in our opinion, mainly composed of a mixture of humic and fulvic acids.

\section{Profile III}

The Ap horizon of this profile showed a lower content of total $\mathrm{C}$ than was the case with the top horizons of Profiles I and II. Furthermore, unlike the situation in Profile II, the content of total $\mathrm{C}$ gradually decreased downwards, i.e. there was no peak in the B2 horizon.

The content of bitumens in total $\mathrm{C}$ in the Ap horizon was much higher than was the case in the A 1(2) and Al horizons of Profiles I and II respectively. Such a high bitumen content is characteristic for soils that have developed under stronger hydromorphic conditions. This means that in the Ap horizon of this soil reducing conditions periodically prevail.

The contents of humins both in soil and in total $\mathrm{C}$ were lower in this profile than in Profiles I and II. In particular, the humin content in total C in the B3 horizon was remarkably low.

The $\mathrm{C}_{\text {h.ac. }} / \mathrm{C}_{\mathrm{f} \text {.ac. }}$ ratios in the $\mathrm{Ap}$ and $\mathrm{B} 2$ horizon were relatively high due to the translocation of fulvic acids from the Ap horizon to the B3 horizon. This phenomenon is confirmed by the fact that the contents of Fraction la both in soil and in total $\mathrm{C}$ increased with depth, and by the results of micromorphological observations, which also in other respects agreed well with the chemical data.

The relatively large dark micro-aggregates that were characteristic of the Ap horizon, are considered to be rather rich in bitumens and humus substances that 
are mainly humic acids of high molecular weight.

In the B2 horizon there were fewer dark micro-aggregates and they were also smaller than those occurring in the Ap horizon. It is possible that these microaggregates like those in the Ap horizon, contain high fractions of bitumens. Furthermore, in the $\mathbf{B} 2$ horizon the sand grains were coated by brownish red, monomorphic (amorphous) humic substances (humicans). It is probable that the humicans are composed mainly of humic substances of low molecular weight. This view fits in very well with the lower $\mathrm{C}_{\text {h.ac. }} / \mathrm{C}_{\text {f.ac. }}$ ratio in this horizon.

In the B3 horizon nearly all organic matter occurred as humicans identical to those of the A2 horizon. This phenomenon is clearly connected to the low $\mathrm{C}_{\mathrm{h} . \mathrm{ac}} / \mathrm{C}_{\mathrm{f} \text {.ac. }}$ in the $\mathrm{Bh} 2$. The very low content of humins in the $\mathrm{B} 3$ horizon is in good agreement with the fact that there were hardly any micro-aggregates.

\section{Conclusions}

From our investigations several conclusions can be drawn.

1. A comparison of the fractional humus compositions of the three podzolic soils investigated did show a distinct difference in the translocation and distribution of the principal humus compounds in the 'Holt' podzol soil on the one hand, and the 'Haar' podzol and the 'Veld' podzol on the other hand.

2. The translocation processes of humus compounds were less pronounced in the 'Holt' podzol soils than in the other profiles. Humic acids isolated from the 'Holt' podzol soil were predominantly characterized by higher molecular weight and contained fewer carboxylic groups compared with the acids extracted from the 'Haar' and 'Veld' podzol. This means that the humic acids in the 'Holt' podzol are less acid and less mobile.

3. The occurrence of a maximum of humins in the B2 horizon of the 'Holt' podzol indicates a pronounced illuviation of very fine remnants of plant tissue, which is in good agreement with the concept of mechanical illuviation proposed by Jongerius (1957) and Jongerius \& Schelling (1960).

4. Translocation processes of humus compounds in solution were most pronounced in the 'Haar' podzol soil and less so in the 'Veld' podzol. In this respect, the removal of fulvic acids from the upper horizons to the $B$ horizons is most striking.

5. The fractional humus composition of the soils investigated played an essential role in the development of micro-aggregates and their water stability, and in the formation of cutans. This was confirmed by micromorphological investigations.

6. In thin sections two kinds of micro-aggregates could clearly be distinguished, i.e. blackish brown to black, usually opaque ones and brownish ones. The first type was dominant in the 'Haar' podzol soil, whereas the 'Holt' podzol was characterized by the brownish micro-aggregates. In the upper horizons of the 'Veld' podzol both types occurred but downwards the brownish type became more dominant.

7. The humic substances of the dark micro-aggregates were mainly composed 
of bitumens, humins and humic acids of higher molecular weight. The humic substances of the brownish micro-aggregates in the 'Veld' podzol mainly consisted of fulvic acids and probably also of humic acids of lower molecular weight. This also holds for the brownish micro-aggregates in the 'Holt' podzol soil, but in this case quite a lot of humins also occurred.

8. The dark micro-aggregates probably have a higher stability than the brownish ones. The lower stability of the brownish aggregates is, in our opinion, due to the high amount of fulvic acids. This also explains the phenomenon of debris cutan formation in the B horizons of the 'Holt' podzol. These cutans are the product of the brown micro-aggregates disintegrating in the $\mathrm{B}$ horizon.

9. The brownish red free grain cutans of the 'Veld' podzol probably mainly consist of fulvic acids, whereas the brown cutans that occurred in the 'Haar' podzol are predominantly composed of fulvic acids, bitumens and some iron-humus complexes.

\section{Acknowledgements}

This work was done thanks to the IAC (Wageningen), which granted fellowships for the first and the third author. The authors are also indebted to Dr A. Breeuwsma (Dept. of Soil Chemistry of the Netherlands Soil Survey Institute) and his co-workers, and to Dr P. Smit of the Department of Organic Chemistry of the Agricultural University Wageningen (the Netherlands) for their help in providing facilities and equipment. They also are very grateful to $\mathrm{Mr} \mathrm{H}$. de Bakker (Dept. of Soil Classification of the Netherlands Soil Survey Institute) for his advice on the correlation between the classification systems indicated in this paper.

\section{References}

Bal, L., 1973. Micromorphological analysis of soils; lower levels in the organization of organic soil materials. Thesis, State University of Utrecht. Soil Survey Paper Wageningen No 6; xiii $+175 \mathrm{pp}$.

Brewer, R., 1964. Fabric and mineral analysis of soils. Wiley, New York, xiii $+470 \mathrm{pp}$.

Bullock, P., U. Babel, C. Jeanson and A. Jongerius, 1978. Report on the activities of the WorkingGroup on Soil Micromorphology of the ISSS. The Sub-Group on Organic Matter. In: M. Delgado (Ed.), Micromorfologia de suelos, Vol. 2: 1417-1428.

Bakker, H. de, 1979. Major soils and soil regions in the Netherlands. Dr. W. Junk Publishers, The Hague/Pudoc, Wageningen, $203 \mathrm{pp}$.

Bakker, H. de \& A. W. Edelman-Vlam, 1964a. 'Holt' podzol soil in pushed preglacial. (Dutch.) Tijdschrift Kon. Ned. Heidemij 75: 361-366.

Bakker, H. de \& A. W. Edelman-Vlam, 1964b. 'Haar' podzol soil in cover sand. (Dutch.) Tijdschrift Kon. Ned. Heidemij 75: 367-372.

Bakker, H. de \& A. W. Edelman-Vlam, 1964c. 'Veld' podzol soil in cover sand. (Dutch.) Tijdschrift Kon. Ned. Heidemij 75: 603-608.

Bakker, H. de \& J. Schelling, 1966. A system of soil classification for The Netherlands. The higher levels. (Dutch, with extensive English summary.) Pudoc, Wageningen, viii $+217 \mathrm{pp}$.

De Coninck, F., D. Righi, J. Maucorps \& A. M. Robin, 1974. Origin and micromorphological nomenclature of organic matter in sandy spodosols. In: G. K. Rutherford (Ed.), Soil microscopy, p. 263-280. The Limestone Press, Kingston (Ont.). 
Drozd, J., 1971. Physico-chemical properties of humic substances of some soils utilized differently. Polish J. Soil Sci. 4: 21-27.

Drozd, J. \& S. Kowalinsky, 1972. Micromorphological and chemical examinations of mechanically resistant soil aggregates. In: S. Kowalinsky \& J. Drozd (Ed.), Soil micromorphology. Zeszyty Problemowe Postepów Nauk Rolniczych 123: 747-759.

FAO, 1974. FAO-UNESCO Soil Map of the World, 1:5000 000, Volume I, Legend. UNESCO, Paris.

Farmer, V. C. \& R. I. Morrison, 1960. Chemical and infrared studies on Phragmites peat and its humic acid. Scient. Proc. R. Dublin Soc., Ser. A 1: 85-104.

Flaig, W., 1971. Organic compounds in soil. Soil Sci. 111: 19-33.

Jongerius, A., 1957. Morphologic investigations of soil structure (Dutch, with extensive English summary.) Thesis, Agricultural University of Wageningen. Bodemk. Studies 2; Versl. landbouwk. Onderz. 63.12,93 pp.

Jongerius, A., 1970. Some morphological aspects of regrouping phenomena in Dutch soils. Geoderma 4: 311-331.

Jongerius, A. \& G. Heintzberger, 1975. Methods in soil micromorphology. A technique for the preparation of large thin sections. Soil Survey Paper Wageningen No 10; $40 \mathrm{pp}$.

Jongerius, A. \& J. Schelling, 1960. Micromorphology of organic matter formed under the influence of soil organisms, especially soil fauna. Trans. 7th int. Congr. Soil Sci. (Madison, USA) II: 702710 .

Kasatochkin, V. I., M. M. Kononova, N. K. Karina \& O. I. Rgorova, 1964. Theses on spectral and Xray investigation of chemical structure of humic substances of soil. Trans. 8th int. Congr. Soil Sci. (Bucharest) III: 81-86.

Kononova, M. M., 1966. Soil organic matter; its nature, its role in soil formation and in soil fertility. Pergamon Press, Oxford, 544 pp.

Kozakiewicz, A., 1966. A new concept of the composition of humus in some types of mineral soils in the light of results obtained with a modified. I. Tiurin method, Part I. (Polish) Rocz. Glebozn. 16: 113-130.

Kużnicki, F., K. Konecka-Betley, A. Kowalkowski \& S. Bialousz, 1974. Systematyka Gleb Polski. (With summary: The classification system of Polish soils.) Rocniki Gleboznawcze 25: 1. Pánstwowe Wydawnictwo Nankowe, Warszawa.

Orlow, D. S., 1968. Adsorption and distribution spectra of P-type humic acids in the USSR soils. (Russian.) Pochvovedenie 10: 49-60.

Rosochacka, J., 1969. Characteristics of infrared absorption spectra of four fractions of fulvic acids, separated by means of the method of W. G. C. Forsyth. (Polish.) Rocz. Glebozn. 20: 333-346.

Sapek, A., 1971. The role of humus substances in the development of podzol soils. (Polish.) Studia Societatis Scientiarum Torunensis, Sectio C 7:86.

Scharpenseel, H. W., E. König \& E. Menthe, 1964. Infrarot- und Differential-Thermo-Analyse an Huminsäureproben aus verschiedenen Bodentypen, aus Wurmkot und Streptomyceten. Z. PflErnähr., Düng., Bodenkd. 106: 134-149.

Scheffer, F. \& B. Ulrich, 1960. Humus und Humusdüngung, Bd. I. Enke, Stuttgart, vii $+266 \mathrm{pp}$.

Schnitzer, M., 1971. Characterization of humic constituents by spectroscopy. In: A. Douglas McLaren \& J. J. Skujins (Ed.), Soil biochemistry, Vol. 2: 60-95. Marcel Dekker, New York.

Schnitzer, M. \& S. U. Khan, 1972. Humic substances in the environment. Marcel Dekker, New York, vii $+327 \mathrm{pp}$

Schnitzer, M., D. A. Shearer \& J. R. Wright, 1959. A study in the infrared of high-molecular weight organic matter extracted by various reagents from a podzolic B-horizon. Soil Sci. 87: 252-257.

Sklodowski, P., 1974. Chemical and physico-chemical investigations of humus compounds and their complexes with metals in podzols developing in different climatic zones. (Polish.) Geodezja 14: 136.

Soil Survey Staff, 1975. Soil taxonomy, a basic system of soil classification for making and interpreting soil surveys. Soil Conservation Service, U.S. Department of Agriculture, Handbook 436. U.S. Government Printing Office, Washington, D.C.

Springer, U. 1934. Farbtiefe und Farbcharakter von Humusextrakten in ihrer Abhängigkeit von der Alkalikonzentration, zugleich ein Beitrag zur Kenntniss der Humustypen. Z. PflErnähr., Düng., 


\section{J. DROZD, A. JONGERIUS AND ST. KOWALINSKI}

Bodenkd. 34: 1-14.

Sytek, J., 1972. Physico-chemical properties of humus substances in illuvial horizons of podzolic soils. (Polish.) Rocz. Glebozn. 23: 165-187.

Theng, B. K. G. \& A. M. Posner, 1967. Nature of the carbonyl groups in soil humic acid. Soil Sci. 104: 191-201.

Tiurin, I. W., 1937. Soil organic matter. (Russian.) Sel'khozgiz, Moscow/Leningrad.

Tiurin, I. W., 1951. Analytical procedure for a comparative study of soil humus. (Russian.) Trudy Pochv. Inst. Dokuchaeva 38: 5.

Turski, R. \& M. Lipinska, 1965. Dynamics of humic acids in cultivated podzolic soils on deep locases. (Polish.) Rocz. Glebozn. 15: 247-250.

Turski, R. \& C. Wincenciak, 1969. Studies in infrared on humic acids of soil on eroded areas. Polish J. Soil Sci. 2: 35-41.

Welte, R., 1956. Zur Konzentrationsmessung von Huminsäuren. Z. PflErnähr., Düng., Bodenkd. 74: 219-227. 